распределение теплового потока в сушильной установке конвейерного типа // Ремонт. Восстановление. Реновация: материалы II Всерос. науч.-практ. конф. Уфа, 2011. - С. 52-54.

7. Сивицкий Д.В., Катруха О.И., Шуленок К.Ю. Интенсификация процесса сушки зерновых культур // Состояние и перспективы инновационного развития АПК. - 2013. - С. 439-445.

8. Сивиикий Д.В., Мухин А.И. Пути повышения интенсивности сушки с сохранением целостности высушиваемого материала // Научный вклад молодых исследователей в сохранение традиций и развитие АПК. - СПб., 2015. - Ч. 1. - С. 342.

9. Хансаев Г.Ф., Алтухова Т.А., Шуханов С.Н. Элементы процесса теплообмена при охлаждении зерна в интенсивных аэродинамических полях // Аграрный научный журнал. - 2015. - № 3. - С. 61-63.

10. Хосни Р.К. Зерно зернопереработка / пер. с англ.; под общ. ред. Н.П. Черняева. - СПб.: Профес- сия, 2006. - 336 с.

Глухарев Владимир Алексеевич, $\partial-p$ техн. наук, проф.

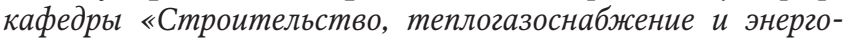
обеспечение», Саратовский государственный аграрный университет имени Н.И. Вавилова. Россия.

Сивицкий Дмитрий Валерьевич, канд. техн. наук, доцент кафедры «Строительство, теплогазоснабжение и энергообеспечение», Саратовский государственный аграрный университет имени Н.И. Вавилова. Россия.

Попов Иван Николаевич, канд. техн. наук, доцент кафедры «Строительство, теплогазоснабжение и энергообеспечение», Саратовский государственный аграрный университет имени Н.И. Вавилова. Россия.

Верзилин Андрей Александрович, ассистент кафедры «Строительство, теплогазоснабжение и энергообеспечение», Саратовский государственный аграрный университет имени Н.И. Вавилова. Россия.

410056, г. Саратов, ул. Советская, 60.

Тел.: (8452) 74-96-50.

Ключевые слова: сушка зерна; сушильная установка; тепло; сушильный агент.

\title{
OPTIMIZATION OF PARAMETERS OF ENERGY UNIT DRYING AGENT FOR GRAIN CROPS DRYING
}

Glucharev Vladimir Alekseevich, Doctor of Technical Sciences, Professor of the chair "Building, Heat, Gas and Energy Supply", Saratov State Agrarian University named after N.I. Vavilov. Russia

Sivitskiy Dmitriy Velerevich, Candidate of Technical Science, Associate Professor of the chair "Building, Heat, Gas and Energy Supply”, Saratov State Agrarian University named after N.I. Vavilov. Russia

Popov Ivan Nikolaevich, Candidate of Technical Science, Associate Professor of the chair "Building, Heat, Gas and Energy Supply", Saratov State Agrarian University named after N.I. Vavilov. Russia

Verzilin Andrey Aleksandrovich, Assistant of the chair "Building, Heat, Gas and Energy Supply", Saratov State Agrarian University named after N.I. Vavilov. Russia
Keywords: grain crops drying; drying unit; heat; drying medium.

This article deals with the questions of defining high-limit temperature of drier agent during the drying of grain depending on the features of the drying process, that may let increase the intencity of the process together with saving the grain integrity without the surface cracking as a result of druing. It is the possibility of increasing the temperature of the drier agent for $10 \ldots 12{ }^{\circ} \mathrm{C}$ that was elicited in comparison with existed recommendations in the period of stated drying speed.

\section{АЭРАЦИОННЫЙ БИОРЕАКТОР-ОБЕЗЗАРАЖИВАТЕЛЬ ПОДСТИЛОЧНОГО НАВОЗА НЕПРЕРЫВНОГО ДЕЙСТВИЯ}

\author{
ГУРЬЯнОВ Дмитрий Валерьевич, Мичуринский государственный аграрный университет \\ ХМЫРОВ Виктор Дмитриевич, Мичуринский государственный аграрный университет \\ ГУРЬЯНОВА Юлия Викторовна, Мичуринский государственный аграрный университет \\ КУДЕНКО Вячеслав Борисович, Мичуринский государственный аграрный университет
}

В статъе рассматривается процесс обеззараживания подстилочного навоза в аэрационном биореакторе, представлен иикл биоферментации подстилочного навоза с тремя температурными зонами. Установлен высокий уровень связи между производительностью цепочно-скребкового транспортера и скоростъю движения. Разработана конструкиия аэрационного биореактора-обеззараживателя непрерывного действия, что необходимо в сельскохозяйственном производстве. Выявлено, что получено органическое удобрение экологически чистое и высокого качества. Срок приготовления органического удобрения из подстилочного навоза в аэраторе-обеззараживателе 5 сут.

Введение. Подстилочный навоз крупного рогатого скота, свиней, овец и помет птицы - основной компонент для производства экологически чистых органических удобрений. Внесение в почву свежего навоза приводит к большим негативным последствиям: загрязняет окружающую среду, почву, водоемы, атмосферу болезнетворными бактериями и гельминтами. В настоящее время разработаны технологии и технические средства для переработки сельскохозяйственных отходов в органические удобрения, такие как аэрационные цеха и биореакторы, но они требуют больших капитальных затрат при загрузке исходного сырья и выгрузке готового органического удобрения. По- 
этому необходимо совершенствовать технические средства для переработки подстилочного навоза непрерывного действия.

Применение органических удобрений позволяет улучшать структуру, плодородие почвы и повышать урожайность сельскохозяйственных культур. Органическое удобрение из отходов сельскохозяйственного производства, где основным компонентом является подстилочный навоз, содержит фосфор, калий и азот.

Аэрационный биореактор - это вертикально расположенная емкость, в которую загружают измельченный подстилочный навоз, последний выравнивается лопастями по всей площади [1]. В биореактор подается по воздуховодным трубам воздух для повышения температуры разложения и сокращения времени аэрации. В верхней части биореактора в подстилочном навозе протекает мезофильный процесс, то есть разогрев массы до $35 . .45^{\circ} \mathrm{C}$. В средней части биореактора наблюдается термофильный процесс: температура доходит до $60 \ldots 65^{\circ} \mathrm{C}$. В нижней части биореактора зона затухания, то есть готовое органическое удобрение.

Цель исследования - разработать конструкцию аэратора-обеззараживателя непрерывного действия для переработки подстилочного навоза в органическое удобрение.

Методика исследований. Для переработки подстилочного навоза и других отходов предлагается конструкция аэрационного биореактораобеззараживателя (рис. 1), состоящая из корпуса 1 , загрузочного скребкового транспортера 2, выравнивающего устройства 3 , цепочно-скребкового транспортера для выгрузки готового удобрения 5 , погрузочного скребкового транспортера готового продукта 6 , завальной ямы 7 , цепи скребкового транспортера 8, скребка 9, аэрационных труб 10, электродов 11, источника питания 12 , электропривода транспортера 13, воздуходувки 14, термопары 15 , микропроцессорного регулятора температуры (МПР) 16.

На рис. 2 представлен цепочно-планчатый транспортер для выгрузки готового органического удобрения.

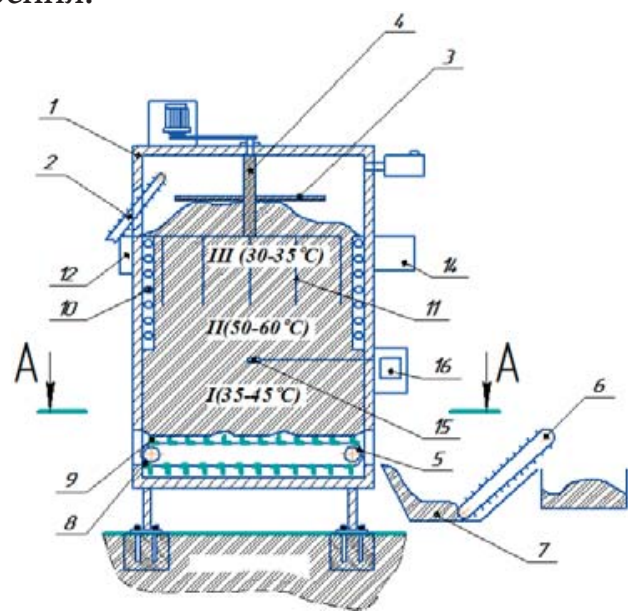

Рис. 1. Аэрационный биореакторобеззараживатель подстилочного навоза: I - зона затухания; II - термофильная зона; III - мезофильная зона
Результаты исследований. Аэрационный биореактор-обеззараживатель работает следующим образом [2]. Измельченный подстилочный навоз влажностью 50-55 \% выдерживается в буртах в течение 3-5 сут.

Далее подстилочный навоз скребковым транспортером 2 загружается в корпус 1 круглой формы с открытым дном, лопасти 3 распределяют исходный материал по всей площади обеззараживателя. Через воздуховодные трубы 10 подстилочный навоз насыщается воздухом, и создаются благоприятные условия в биореакторе для развития мезо- и термофильной микрофлоры, что приводит к интенсивному разложению органической массы и температура резко повышается до $60 . . .70{ }^{\circ} \mathrm{C}$, а электроды 11 создают электрическое поле в органической массе и уничтожают болезнетворные бактерии и гельминты. При температуре $40 . . .45^{\circ} \mathrm{C}$ в зоне затухания включается электропривод цепочно-скребкового транспортера и происходит выгрузка готового экологически чистого органического удобрения.

При выгрузке компостируемый материал медленно перемещается в цилиндрическом корпусе биореактора вниз за счет гравитационных сил, а сверху загружается измельченный подстилочный навоз. Такая конструкция аэрационного биореактора-обеззараживателя обеспечивает поточный способ производства органических удобрений и сокращает погрузочно-разгрузочные операции [3].

Цикл биоферментации подстилочного навоза представлен на рис. 3.

После загрузки подстилочного навоза в биоферментатор включается воздуходувка и воздух по аэрационным трубам подается в органическую массу, таким образом происходит активная аэрация. Температура в биореакторе поднимается до $60{ }^{\circ} \mathrm{C}$, сигнал с датчиков температуры (термопар) подается на МПР-1 и отключается воздуходувка. На рис. 3 представлены три зоны цикла биоферментации: зона А разогрева органической массы (мезофильная); зона В (термофильная), где происходит разложение массы; зона затухания С, удобрение подготовлено к выгрузке из биореактора.

Производительность выгрузного цепочноскребкового транспортера определяется по формуле:

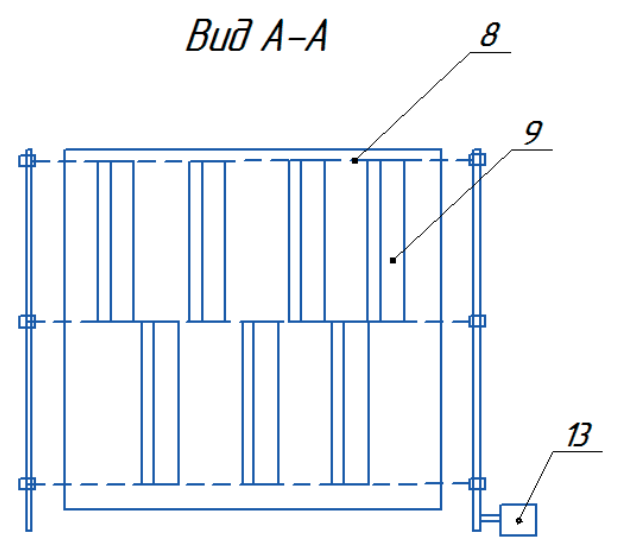

Рис. 2. Цепочно-скребковый транспортер выгрузки готового органического удобрения из аэрационного биореактора-обеззараживателя 


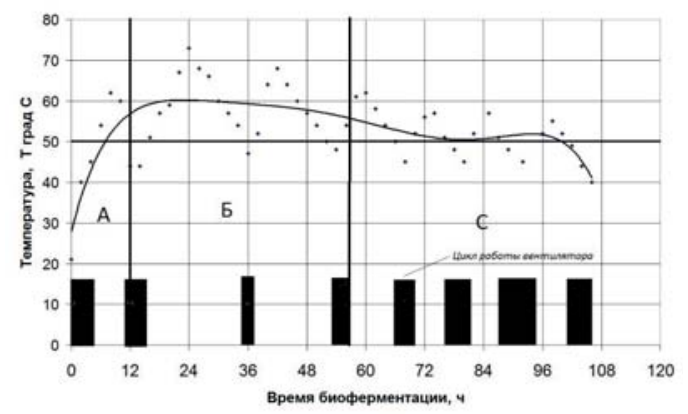

Рис. 3. Температурограмма биоферментации подстилочного навоза: А - зона разогрева (мезофильная); Б - зона горения (термофильная);

$$
\begin{aligned}
& \text { C-зона затухания } \\
& Q=F \gamma \cup T, \mathrm{~T} / \mathrm{T},
\end{aligned}
$$

где $F$ - площадь сечения груза скребкового транспортера, м; $F$ = ab; $a$ - высота скребка, м; $b$ - ширина скребка, м; $\gamma$ - насыпная плотность органического удобрения, т/ $\mathrm{M}^{3}$; v - скорость движения скребков транспортера, м/с; T- время работы цепочноскребкового транспортера, ч.

Зависимость производительности цепочноскребкового транспортера от скорости представлена на рис. 4.

Из рис. 4 видно, что производительность цепочно-скребкового транспортера при скорости $1 . .3 \mathrm{M} /$ с составляет $80 . . .208$ кг/ч, а при увеличении скорости производительность снижается, так как уменьшается площадь сечения груза из-за коэффициента наполнения пространства между скребками.

Заключение. Разработанная конструкция аэрационного биореактора-обеззараживателя работает непрерывным способом, не требует дополнительных погрузочно-разгрузочных операций.

Полученное органическое удобрение экологически чистое, высокого качества и не содержит болезнетворных бактерий и гельминтов.

Разработанная конструкция цепочно-скребкового транспортера позволяет полностью выгрузить готовое органическое удобрение из биореактора с производительностью 80...208 кг/ч.

\section{СПИСОК ЛИТЕРАТУРЫ}

1. Аэрационный биореактор: пат. 2310631 Рос. Федерация: МПК C2 C05 F 3/06 / Миронов В.В.,

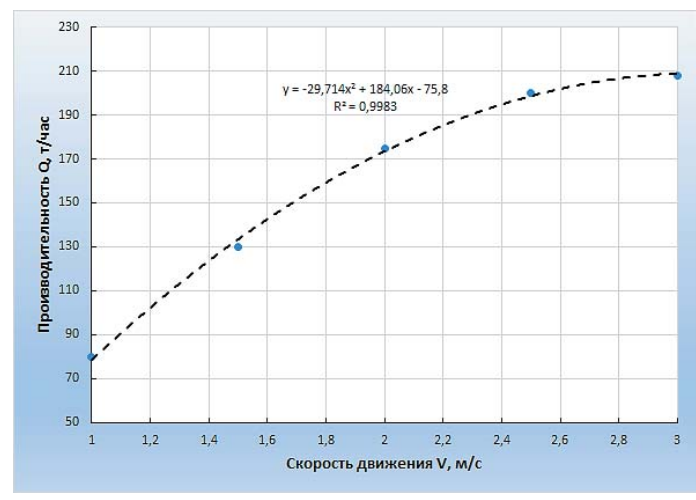

Рис. 4. Зависимость производительности цепочно-скребкового транспортера от скорости

Хмыров В.Д., Никитин П.С., Колдин М.С.; патентообладатель- МичГАУ. - № 2004132670/12; заявл. 20.04.2006; опубл. 20.11.2007, Бюл. №32.

2. Аэрационный биореактор-обеззаживатель органической массы / Д.В. Гурьянов [и др.] // Вестник Мичуринского ГАУ. - 2017. - № 2. - С. 109-114.

3. Биореактор для конверсии органических отходов непрерывного действия: Патент на полезную модель РФ 146604 / Брюханов А.Ю., Васильев Э.В., Максимов Н.В., Уваров Р.А.; заявл. 03.06.2014.

Гурьянов Дмитрий Валерьевич, канд. техн. наук, доцент кафедры «Агроинженерия, электроэнергетика и информационные технологии», Мичуринский государственный аграрный университет. Россия.

Хмыров Виктор Дмитриевич, $\partial-p$ техн. наук, проф. кафедры «Технологические процессы и техносферная безопасность», Мичуринский государственный аграрный университет. Россия.

Гурьянова Юлия Викторовна, $\partial-p$ c.-х. наук, проф. кафедры «Садоводство», Мичуринский государственный аграрный университет. Россия.

Куденко Вячеслав Борисович, канд. техн. наук, доцент кафедры «Агроинженерия, электроэнергетика и информационные технологии», Мичуринский государственный аграрный университет. Россия.

393760, Тамбовская область, г. Мичуринск, ул. Интернаииональная, 101.

Тел.: (8475 45) 9-45-01.

Ключевые слова: подстилочный навоз; аэрационный биореактор-обеззараживатель; иикл биоферментации; экологически чистое органическое удобрение.

\section{AERATING BIOREACTOR-DISINFECTANT OF LITTER MANURE OF CONTINUOUS ACTION}

Guryanov Dmitriy Valeryevich, Candidate of Technical Sciences, Associate Professor of the chair "Agroengineering, Power Engineering and Information Technologies", Michurinsk State Agrarian University. Russia.

Khmyrov Viktor Dmitriyevich, Doctor of Technical Sciences, Professor of the chair "Technological Processes and Technosphere Safety”, Michurinsk State Agrarian University. Russia.

Guryanova Yuliya Viktorovna, Doctor of Agricultural Sciences, Professor of the chair "Horticulture", Michurinsk State Agrarian University. Russia.

Kudenko Vyacheslav Borisovich, Candidate of Technical Sciences, Associate Professor of the chair "Agroengineering, Power Engineering and Information Technologies", Michurinsk State Agrarian University. Russia.
Keywords: litter manure; aerating bioreactor-disinfectant; biofermentation cycle; environmentally friendly organic fertilizer.

The article discusses the process of decontamination of litter manure in the aerating bioreactor, presents a cycle of biofermentation of litter manure with three temperature zones. A high level of connection between the performance of the chain-scraper conveyor and the speed of its scrapers is established. It has been developed a design of the aerating bioreactor-disinfectant of continuous action that is necessary in agricultural production. It has been revealed that produced organic fertilizer is ecologically clean and of high quality. The period of production of organic fertilizer from litter manure in the aerator-disinfectant is 5 days. 